\title{
Performance Assessment of State Senior High School Teachers Aged 56 Years and Above ${ }^{1}$
}

\section{Yusrizal}

Prof., Evaluation of Education, Teacher Training and Education Faculty, Syiah Kuala University, Daarussalam-Aceh, Indonesia, yusrizal_fkipunsyiah@yahoo.co.id

\section{Cut Zahri Harun}

Prof., corresponding author, Teacher Training and Education Faculty, Syiah Kuala University, Darussalam-Aceh, Indonesia, profcut@unsyiah.ac.id

\section{Husen}

Lecturer, Teacher Training and Education Faculty, Syiah Kuala University, Indonesia

\section{Muhammad Iqbal}

Lecturer, Teacher Training and Education Faculty, Syiah Kuala University, Indonesia

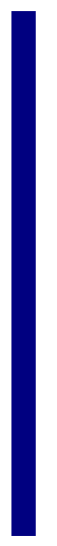

This research aimed at determining the level of performance of state senior high school (Sekolah Menengah Atas Negeri abbreviated as SMAN) teachers aged 56 years and older. The research population was all SMAN teachers aged 56 years and older in Banda Aceh Municipality, Districts of Aceh Besar, Pidie and Pidie Jaya. Performance assessment instruments developed were tested for construct validity by factor analysis techniques, and reliability estimated by using Cronbach Alpha formula. The levels of teacher performance are grouped in five categories as: very high, high, medium, low and very low. The results show that the five components of the SMAN teachers' performance aged 56 years and older were at "very high" category, namely: learning strategies, mastery of materials, classroom management, communication between teachers and students, and teaching techniques. Another performance component, assessment of students learning outcomes was at "medium" category. So, it was found that the performance of SMAN teachers aged 56 years and above was very high.

Keywords: assessment, teacher, validity, reliability, performance assessment, high school, performance of teachers

\footnotetext{
${ }^{1}$ This article has been seminar in the Research and Community Service Institutions of Syiah Kuala University at December 9th 2015.

Citation: Yusrizal, Harun, C. Z., Husen, \& Iqbal, M. (2018). Performance Assessment of State Senior High School Teachers Aged 56 Years and Above. International Journal of Instruction, 11(1), 33-46. https://doi.org/10.12973/iji.2018.1113a
} 


\section{INTRODUCTION}

Related to improving the quality of education, the teachers as the spearhead of education play an important and decisive role in achieving national education goals. According to Idrus and Fachrudin (2009: 30) the quality of education cannot be separated from the competence of teachers as professionals. High and low quality of student learning outcomes depends mostly on the ability of teachers to teach. Teachers have an important role in the learning process. Teachers may act as presenters of material, as well as assessors. According to Barinto (2012: 202), a teacher is a crucial component in the success of an education, because he or she is spearhead that contacts directly with students as subjects and objects of study. If teachers have a good ability in teaching, it will bring the impact on the climate of good teaching and learning. Having full library, sophisticated laboratory, the availability of computers and internet would have no meaning in improving the quality of education if the teachers are not qualified and do not love their profession. Teachers' quality is a high-performing teacher indicated by the mastery of the material that will be taught (what to teach) while mastering the methods and techniques used to teach (how to teach) the students.

The number of SMAN teachers in Aceh province is relatively insufficient. The data from the Aceh Provincial Education Department shows that there are 12060 teachers in Aceh province, but the quality of education in Aceh is still in "low" category. The low quality of education in Aceh seen from the data of teacher competition test at national level 2012 shows the quality of teachers in Aceh is ranked at 28 out of 33 provinces in Indonesia. The ability of the senior high school graduates (SMA / SMK / MA) that can pass the university entrance test at state universities is nationally ranked at 31 (Serambi Indonesia, 03/01/2013).

From the number of teachers, there are about 1385 people aged between 50-59 years (Aceh Provincial Education Department). It is estimated that most of the teachers aged 56 years and above. The aging of humans are developmental stages in the human life cycle. On the positive side, teachers aged 56 years and above are teachers who have long taught, are increasingly capable of mastery of the field of study being taught and the level of their understanding of students is higher and the level of proficiency they have is also high.. In short, teachers who have long taught have a high level of proficiency. According to Purwanto (2003: 104), "the more often a person experiences something, the more knowledge and skills to those things, and he will master, so from experience that a person can try to get good results". However, the ages of 55 to 65 years are age groups that reached a praenisium stage, at which stage people will experience a variety of immunological suppression / health such as physical strength, sensory, intellectual potential and capacity decreased and so on. Disruption of intellectual capacity is closely related to cognitive function in old age (Tobing, 2006). According to Surbakti (2012: 7) one of the essential weaknesses of middle aged group is a bad arrangement of memory, so that data stored in brains are not continuous. Allegedly one of the low qualities of education in Aceh is the poor performance of teachers aged 56 years and above. Therefore, this study is worth doing. 
Based on the previous description, the aim of this study is to determine the performance level of SMAN teachers aged 56 years and above. Information on the performance level of SMAN teachers aged 56 years and above becomes an input for Aceh Provincial Education Department and District/City Education Department in developing teachers' quality, particularly with respect to the competency of teachers. For schools, teachers' performance level information can be used as the basis to improve and stimulate the creativity of teachers and to improve their capabilities and skills. As for the teachers, the level of their performance information can be used as self-introspection, so the teachers can repair themselves optimally to improve their performance in carrying out their professional duties. Although the schools of teachers aged 56 years and above are not distinguished from other teachers, the results of this study becomes very important to determine the effect of age on the task of his profession as a teacher. Furthermore, until now there has been no research related to the performance of elderly teachers.

\section{Review of Literature}

In essence the performance of teachers is the behavior generated by a teacher in carrying out his duties as educator and teacher when teaching in front of the class, in accordance with certain criteria. According to Byars\& Rue (1991: 25 )" Performance refers to the degree of accomplishment of the tasks that make up an individual's job. It reflects how well an individual fulfilling the requirements of a job ". Performance refers to the degree of completion of tasks that complement someone works. Added by Berk (1986: 237) "performance on a job function is the record of outcomes achieved in carrying out the job function during a specified period." That is, the performance is a record of the results achieved in completing the work during a certain period. Furthermore, Cascio (1995: 275) states that the performance is a display of achievement in completing any duties. It means, a person's performance is associated with routine tasks to be done. As a teacher, a regular duty is teaching, and then the activity shown optimally from these tasks is a teacher's performance. This is in line with Suprahatiningrum (2013: 124) who states that the performance of teachers is outcome, the records generated from a job function or activity during the teaching-learning process.

Saud (2010: 36) states that the actual performance of the teaching profession in the learning process consists of planning, implementing, assessing and master the teachinglearning process at minimum level. Sanjaya (2005:13-14) suggests that teacher performance is associated with planning, learning management and assessment of student learning outcomes. Tasks and role of teachers, among others, are mastering and developing teaching materials, planning and preparing daily lessons, controlling and evaluating learning activities (Sardiman, 2000: 142). So the performance of a teacher is a teacher work or task related to learning strategies, mastery of teaching materials, classroom management skills, and the ability to assess students' learning outcomes in order to obtain better results to achieve the learning objectives.

Teacher performance is the result achieved by the teacher in carrying out the tasks assigned to him based on skills, experience and seriousness and the use of time. The teacher's performance will be good if the teacher has implemented elements consisting of loyalty and high commitment to teaching tasks, mastering and developing 
instructional materials, discipline in teaching and other tasks, creativity in the implementation of teaching, cooperation with all citizens in the school, leadership that becomes role models for students, as well as responsibility for their duties.

Shackelford and Henak (Soekartawi, 1995: 37) provide ten criteria in an effort to define the characteristics of effective teachers, namely (a) having an enthusiastic, (b) having communication skills, (c) being able to clearly explain the subject or topic; ) Master the teaching materials, (e) able to make the classroom atmosphere come alive, (f) being flexible, (g) giving the teaching material neatly organized in accordance with the syllabus, (h) being fair in giving value, (i) willing to receive feedback, and ( $\mathrm{J}$ ) being familiar with the class situation.

Riyanto (2003: 48) suggests that teaching components include (1) objectives, (2) materials, (3) methods, (4) teachers, (5) students, (6) facilities, (7) interactions, and (8) evaluation. Sumiyati (2005) suggests that teacher performance is a teacher activity in conducting learning and which can be observed by students which include: (1) class management, (2) personal qualities, (3) teacher-teacher relations, (4) teaching techniques, 5) behavior. Furthermore, it is still related to the teaching and learning process,. Mcbeath (1992: 21) suggests that in preparing the lesson the teacher should: (1) select the material, (2) organize the material, (3) choose the examples and sources, (4) format the presentation, (5) create conditions for successful learning, (6) evaluate the effectiveness of learning, (7) make summaries, and (8) assign tasks.

Based on the above description, then in this study it is meant by the performance of $S M A N$ teachers aged 56 years and above that the activity of the SMAN teachers in implementing learning and can be observed by students, which includes (1) learning strategies, (2) mastery of material, 3) class management. (4) teachers' communication with students, (5) teaching techniques, and (6) assessment of students' learning outcomes. The performance of teachers and their constructs is as shown in Figure 1 below. 


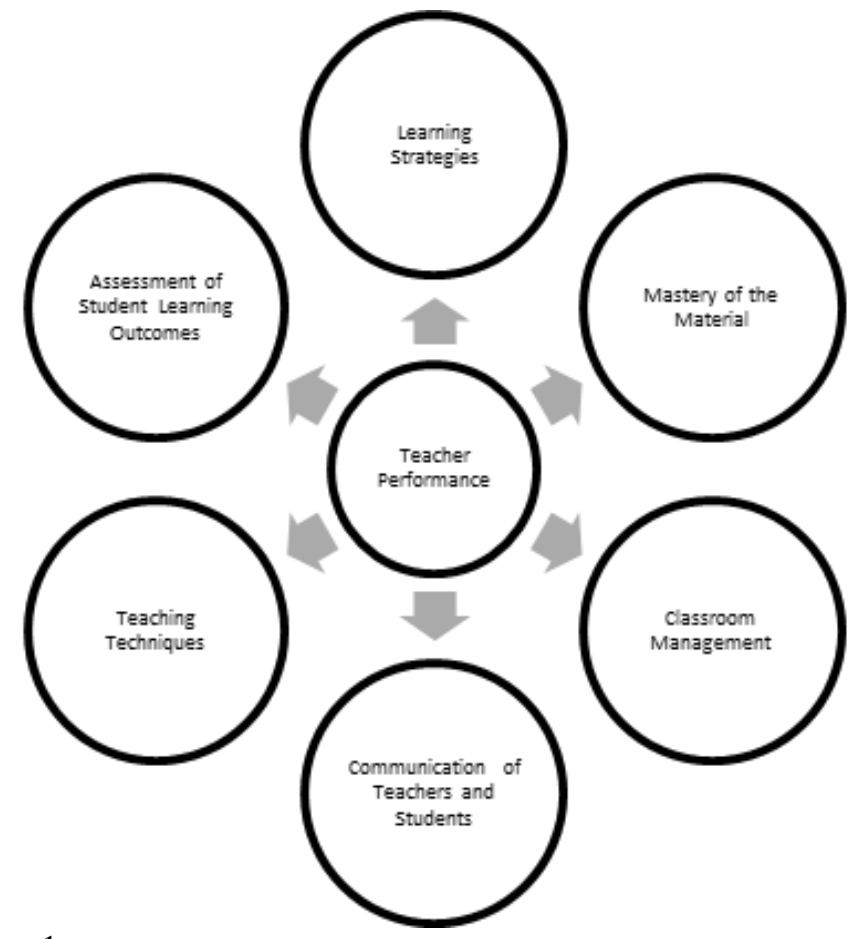

Figure 1

Teacher Performance and Constructions

The understanding of each construct performance of teachers aged 56 years and above, is namely:

Learning Strategy is the way that will be used by the teacher to choose the learning activities to be used during the learning process" (Uno, 2008: 3).

Mastery of materials is a teacher who has a high mastery of material competence and who is expected to teach all subject matter to students completely and optimally, so as to achieve learning objectives (Fahmi, 2013).

Classroom management is a teacher's skill to create and maintain optimal learning conditions and restore them in the event of learning disruption (Djamarah and Aswan Zain, 2006: 194).

Communication of teachers and students in learning activities is face to face communications both verbally and non-verbally, either individually or in groups and assisted with media or learning resources.

The teaching technique is the presentation technique mastered by the teacher to teach or present the lesson material which can be captured, understood, and applied by the students well (Roestiyah, 1988). 
Assessment of students is a process of obtaining information used for decision making of students (Nitko and Brookhart, 2007). On the other hand, learning outcomes are the abilities of students to meet a stage of learning experience achievement in one basic competency (Kunandar 2007). So, assessment of learning outcomes is the process of giving or determining values to students based on a certain criteria.

Performance is a decisive mean in achieving the goals of an institution or a company; however, this is not easy to do, because many factors affect the high and the low performance. One factor that can affect performance is the age factor. Permanasari (2001) shows that there are differences in job performance due to age factor. The results of the McEvoy \& Cascio study also show that age is negatively related to performance (Supriyono, 2006: 59).

Assessing the performance of teachers is an activity to determine the success of teachers in doing the work or tasks with good results that include learning strategies, mastery of materials, classroom management, teaching techniques, and assessment of student learning outcomes. A teacher performance assessment is an important part of the whole process of the teacher performances (Susanto, 2012: 200). According to Handoko (2001), assessment acts as feedback on the things such as ability, fatigue, deprivation and potential which in turn are useful for determining the goals, ways, plans and career development.

\section{Research Question}

What is the level of performance of high school teachers who are aged 56 years and above?

\section{METHOD}

\section{Research Design}

This research is a research development and survey. Therefore, this research is conducted in two stages: firstly developing the instrument of performance appraisal (questionnaire) and the second phase is to survey the SMAN teachers who are aged 56 years and above. The data were collected by a questionnaire developed by the researchers, namely by providing a list of questions written in writing to the respondents (students) are taught by teachers aged 56 years and over.

\section{Population}

The population in the study was all SMAN teachers aged 56 years and over, who were 200 people. The sample used is $45 \%$ of the population that is 80 teachers from 20 SMAN. The samples were randomly assigned as 4 teachers from each school.

The selected school for this study is a school with teachers aged 56 years and over. The determination of the school is based on the information of the local District Education Office. The determined schools for the study are: 
Table 1

List of School Names selected for the study

\begin{tabular}{|c|c|c|}
\hline Region & School Names & Information \\
\hline \multirow[t]{5}{*}{ Banda Aceh } & SMAN 2 Banda Aceh & \multirow{5}{*}{$\begin{array}{l}\text { School of existing } \\
\text { teachers aged } 56 \\
\text { years and above }\end{array}$} \\
\hline & SMAN 3 Banda Aceh & \\
\hline & SMAN 4 Banda Aceh & \\
\hline & SMAN 8 Banda Aceh & \\
\hline & SMAN 11 Banda Aceh & \\
\hline \multirow[t]{5}{*}{ Aceh Besar } & SMAN 1 Darul Imarah & \multirow{5}{*}{$\begin{array}{l}\text { School of existing } \\
\text { teachers aged } 56 \\
\text { years and above }\end{array}$} \\
\hline & SMAN 1 Suka Makmur & \\
\hline & SMAN 1 Indrapuri & \\
\hline & SMAN 1 Montasik & \\
\hline & SMAN 1 Barona Jaya & \\
\hline \multirow[t]{5}{*}{ Pidie } & SMAN 1 Sigli & \multirow{5}{*}{$\begin{array}{l}\text { School of existing } \\
\text { teachers aged } 56 \\
\text { years and above }\end{array}$} \\
\hline & SMAN 1 Mutiara & \\
\hline & SMAN 1 Kota Bakti & \\
\hline & SMAN 1 Kembang Tanjong & \\
\hline & SMAN Glumpang Tiga & \\
\hline \multirow[t]{5}{*}{ Pidie Jaya } & SMAN 1 Meurudu & \multirow{5}{*}{$\begin{array}{l}\text { School of existing } \\
\text { teachers aged } 56 \\
\text { years and above }\end{array}$} \\
\hline & SMAN 1Trienggadeng & \\
\hline & SMAN 1 Bandar Baru & \\
\hline & SMAN 2 Bandar Baru & \\
\hline & SMAN 1 Bandar Dua & \\
\hline
\end{tabular}

To see the level of performance assessment results, the categorization by Azwar (2012: 148 ) is used as shown in Table 2:

Table 2

The Numeric Representations of Scores and Categorization of Teacher Performance

\begin{tabular}{lll}
\hline No & Numeric Representations & Categorization of Teacher Performance \\
\hline 1 & $\mathrm{X} \leq(\mu-1,5 \sigma)$ & Teachers have a very low performance \\
\hline 2 & $(\mu-1,5 \sigma)<\mathrm{X}<(\mu-0,5 \sigma)$ & Teachers have a low performance \\
\hline 3 & $(\mu-0,5 \sigma)<\mathrm{X} \leq(\mu+0,5 \sigma)$ & Teachers have a medium performance \\
\hline 4 & $\mu+0,5 \sigma)<\mathrm{X}(\mu+1,5 \sigma)$ & Teachers have a high performance \\
\hline 5 & $(\mu+1,5 \sigma)<\mathrm{X}$ & Teachers have a very high performance \\
\hline
\end{tabular}

with $\mu=1 / 2$ (highest score + lowest score) $\sigma=1 / 6$ (highest score - lowest score)

\section{Research Instrument}

The instrument used in this research is the developed teacher performance appraisal instrument (questionnaire). This research instrument was developed by researchers and validated by evaluation experts from Jakarta State University (UNJ). Performance assessment instrument of SMAN teachers used the type of semantic differential scale, which has seven answers. The construct validity is determined by the technique of factor analysis and reliability of the instrument tested with Cronbach alpha formula. The data 
obtained from the instrument were analyzed using Microsoft Excel program. The research was conducted on March until December 2015.

\section{FINDINGS}

\section{Development of instruments (questionnaires)}

The development of teacher performance assessment instruments (questionnaire) for this research was conducted following these steps: (1) conducting theoretical studies to formulate indicators of the teachers performance (2) arranging grating instruments (3) writing grains statement (4) reviewing by expert (5) preparing the test (6) analyzing the test results (7) revising (8) and reassembling the grains to become a research instrument (Djaali and Muljono, 2007: 81-85; Suryabrata, 2005: 31; Gable, 1986: 70-77). The procedure of development of research instrument is as follows. The first step is to review a number of studies in literature to determine the constructs of teacher performance aged 56 years and above. The results of the studies of the various theories on the teacher performance can be formulated in six constructs of teacher performance, namely: (1) learning strategies, (2) mastery of the material, (3) classroom management, (4) communication of teachers and students, (5) teaching techniques, and (6) the assessment of student learning outcomes (Sumiyati, 2005: 4; Soekartawi, 1995: 37-38; Riyanto, 2003: 47). In the following table, grating assessment performance instrument of SMAN teachers aged 56 years and above is given.

Table 3

Grating assessment performance instrument of SMAN teachers aged 56 years old

\begin{tabular}{lll}
\hline No & Construct & Corresponding of Question Questionaire \\
\hline 1 & learning strategies & $1,2,3,4,5,6,7,8$ and 9 \\
\hline 2 & mastery of the material & $10,11,12,13,14,15,16,17$ and 18 \\
\hline 3 & classroom management & $19,20,21,22,23,24,25,26,27,28$ and 29 \\
\hline 4 & communication of teachers and students & $30,31,32,33,34$ and 35 \\
\hline 5 & teaching techniques & $36,37,38,39,40,41$ and 42 \\
\hline 6 & assessment of student learning outcomes & $43,44,45,46$ and 47 \\
\hline
\end{tabular}

The next step is to write instrument points based on teacher performance constructs. Instrument items are created for each construct. Each construct is developed into several statement items. Of the six constructs developed a total of 47 items statement are written, with details as follows. For instructional strategy constructs there are 9 items, construction of material mastery is 9 points, construction of class is 11 grain management, communication with students is 6 points, for teaching techniques there are 7 points, and for construct assessment of learning outcomes there are 5 points.

After the instrument draft is completed, a theoretical construct matching test is performed. Assessment is conducted by Lecturer of Education Research and Evaluation of Universitas Negeri Jakarta. The result of the expert study was improvement of editorial of some point statements and suggestions were to remove two items because there was an intentional similarity with other grains. 
In the field experiment (empirical) the instrument used is a revised instrument based on an expert input consisting of 45 items of statement. According to Gabel (1986) the number of non-cognitive instrument test subjects is: 5, 6, 7, 8, 9, 10 numbered questions. Therefore this instrument is tested by 300 high school students in four districts / cities, namely Banda Aceh, Aceh Besar, Pidie, and Pidie Jaya. The respondents were the students who were taught by teachers aged 56 years and over. Therefore, the school that is used as a test site is a school that there are teachers aged 56 years and above. The school is selected / shown by the local Education Office.

Of the 300 questionnaires were distributed to the respondents (students) and all the questionnaires were returned well, so the questionnaire return rate was $100 \%$. Because the data collection is conducted using questionnaires, the questionnaire of the development results tested the validity and reliability. Test of construct validity is done by using factor analysis technique, while reliability test is done by using Cronbach alpha formula.

Testing of construct validity using factor analysis is done by the following test procedure: first, Bartlett's test of sphericity is a statistical test used to test the hypothesis that the variables are not correlated in the population, secondly, Emperor-Meyer-Olkin (KMO) Measure of Sampling Adequacy is an index used to examine the accuracy of factor analysis, third, communality, is the number of variants contributed by a variable with all other variables in the fourth analysis, Eigenvalue is the number of variants described by each factor, the fifth, the Scree Plot, is a plot of the eigenvalue as the vertical axis and the number of factors as the flat axis to determine the number of extractable factors (the extract factor), the six, the Loadings Factor, is a simple correlation between the variable and the factor.

The result construct validity-testing instrument by using SPSS for Windows version 17.0, the value of KMO instrument was found as 0.90. This value greater than 0.50 means that the factor analysis can proceed to analyze the data in the form of a correlation matrix. Then, the value of Bartlett's test of Sphericity obtained for the degrees of freedom was 7617.49 , for the degrees of freedom of 948 there was a significance level of $0.00<0.05$, thus the correlation matrix is formed instead of the identity matrix, so the factor analysis can proceed.

In Table Total Variance Explained, for 45 items included in the factor analysis, there are six factors which have a characteristic root of (eigen value) above $1(\geq 1)$, so it was the same as the estimation. It can be concluded that the performance assessment instruments of SMAN teachers aged 56 years and above has qualified construct validity. The results of the rotated matrix component conducted as eight rounds shows that there are 4 items that pass load factor "cut off point". The items smaller than $0.30(<0.30)$ are excluded from the draft instrument. So, the items selected for the instrument is 41 grains.

The reliability coefficient of the instrument was analyzed using alpha formula $(\alpha)$ and Cronbach was found as obtained 0.94 . 
Thus, it can be stated that the performance assessment instruments of SMAN teachers aged 56 years and above were developed for this study and the construct validity and reliability are good, very high.

\section{Teacher Performance Assessment}

The results of the analysis instrument that was completed by 300 students of 20 SMAN in four cities / districts are as follows:

\begin{tabular}{llllll}
\hline Construct & Very High & High & Medium & Low & Very Low \\
\hline Learning Strategies & $155(52 \%)$ & $103(34 \%)$ & $33(11 \%)$ & $9(3 \%)$ & --- \\
\hline $\begin{array}{l}\text { Mastery of the } \\
\text { Material }\end{array}$ & $272(91 \%)$ & $23(8 \%)$ & $4(1 \%)$ & --- & --- \\
\hline $\begin{array}{l}\text { Classroom } \\
\text { Management }\end{array}$ & $286(95 \%)$ & $12(4 \%)$ & $2(1 \%)$ & --- & --- \\
\hline $\begin{array}{l}\text { Communication of } \\
\text { teachers and students }\end{array}$ & $177(59 \%)$ & $88(29 \%)$ & $25(8 \%)$ & $5(2 \%)$ & $5(2 \%)$ \\
\hline Teaching techniques & $177(59 \%)$ & $84(28 \%)$ & $29(9 \%)$ & $8(3 \%)$ & $2(1 \%)$ \\
\hline $\begin{array}{l}\text { Assessment of } \\
\text { Student learning } \\
\text { outcomes }\end{array}$ & $42(14 \%)$ & $54(18 \%)$ & $110(37 \%)$ & $48(16 \%)$ & $46(15 \%)$ \\
\hline
\end{tabular}

\section{DISCUSSION}

Based on the analysis of the performance of SMAN teachers aged 56 years and above the results show that performance constructs are: (a) learning strategies, (b) mastery of the material, (c) classroom management, (d) the communication of teachers and students, and (e) teaching techniques are in very high category. The assessment of student learning outcomes components is in the medium category. The high performance of the teachers is due to their high motivation to teach. The motivation is high because of certification allowances. The high performance of teachers - aged 56 and above in the construction (Learning Strategies, Mastery of the Material, Classroom Management, Communication of teachers and students, and Teaching techniques) is because of the experience factor, that is, they have taught. Teachers who have long taught, is believed to improve performance. Purwanto (2001: 104) argues that "the more often a person experiences something, the more his knowledge and skill will be over those things, and he will be more masterful, so that from his experience one can try to get good results."

In Learning Strategies, showing $52 \%$ of very high performers means that teachers aged 56 years and over are able to use learning methods in accordance with the material it conveys. This is supported by Ministry of Education (2008: 22) stating that "the ability of teachers in carrying out learning activities at least teachers are able to use learning methods in accordance with the material to be delivered and the use of media facilities and learning resources that have been available and design your own.

Mastery of the Materials and Teaching techniques of teachers are also dominated in very high categories as $91 \%$ and $59 \%$, respectively. The long teaching experience of teachers aged 56 years and over, makes the teacher in-depth in subject matter or subject matter about which is taught and how to teach it to the students. That is, understanding of 
materials and teaching techniques are two things that cannot be separated. Djamarah and Aswan Zain (2006: 112) argued that "In pursuing the field of duty, the experience of teachers is always increasing, when the period of work is more, the teacher is more and more experienced the level of difficulty found by teachers in learning increasingly reduced on certain aspects as the experience increases as a teacher."

Related to Classroom Management, it shows that there are $95 \%$ of teachers are very high performers, meaning that teachers aged 56 years and over have been successful in involving students in learning effectively. This is in line with Danim (2002: 189) showing that effective classroom management performance is reflected in teacher success in creating positive learning environments and empowering students to understand and be effective in involving themselves in the process of classroom management. Rohani (2004) also stated that corrective action of class management is an absolute requirement for effective teaching and learning process.

Construct Communication of teachers and students show that there is $59 \%$ in high category because teachers aged 56 years and over realize that their role in student coaching through good communication between teacher and student is crucial for the early life of human being. Teachers aged 56 years and over already use a communication model that involves students to be more active and able to interact.

Construct Assessment of Student learning outcomes show that $42 \%$ of teachers are in low category. This is surprising, because according Purwanto (2013: 22) assessment of student learning outcomes is one activity that is a liability for each teacher or teacher.

It is acknowledged that the difficult component for teachers in the classroom is when assessing student learning outcomes. The result of Ruslan's research, Tati Fauziah, Tuti Alawiyah (2016) which shows that "The obstacles experienced by teachers in designing and executing the assessment are the compilation of the many questions, the format is too complicated to make teachers overwhelmed in the assessment of each student." Related to the performance of teachers in the components of learning achievement, Yusrizal, Soewarno S and Zarlaida Fitri (2011: 77) also found that the performance of high school physics, biology and chemistry teachers who have passed the certification is still apprehensive, because no teacher is in the component. This is in the high performance category.

The inability of teachers to evaluate learning outcomes will have implications for the poor quality of learning. To improve the quality of learning requires information about the implementation of previous learning. It can be obtained by the assessment of the process and the learning outcomes periodically (Widoyoko, 2013).

\section{CONCLUSION}

The performance level of SMAN teachers aged 56 years and above is in very high category for the components: (a) learning strategies, (b) mastery of the material, (c) classroom management, (d) the communication of teachers and students, and (e) teaching techniques, while the other component, the assessment of student learning outcomes is in the medium category. 


\section{SUGGESTIONS}

The suggestion from this study is intended to provide recommendations for the parties concerned and to have authority in an effort to improve the quality of education. For the heads of the District/City Education Departments of Banda Aceh, Aceh Besar, Pidie and Pidie Jaya it is suggested that they offer trainings to teachers on technical assessment of learning outcomes which include ways of preparing test items, item analysis, ways of determining the validity and reliability problems, techniques in compiling standard questions and technique to develop questions for higher level skills of education for all $S M A N$ teachers in each region.

\section{REFERENCES}

Azwar, S. (2012). Penyusunan skala psikologis. Yogyakarta: Pustaka Pelajar

Barinto (2012). Hubungan Kompetensi Guru dan Supervisi Akademik dengan Kinerja Guru SMP Negeri Se-Kecamatan Percut Sei Tuan, Jurnal Tabularasa PPS Unimed, 9(2), $201-214$.

Berk, R.A. (1986). Performance Assessment. London: The Johns Hopkins Press Ltd.

Byars, L. L., \& Rue, L. W. (1991). Human resource management. Boston: Irwin Inc. Donald

Cascio, W. E. (1995). Managing Human Resource (USA :McGraw-Hill, Inc.

Danim, S. (2002). Inovasi pendidikan. Bandung: Pustaka Setia.

Depdiknas (2008). Penilaian kinerja guru. Jakarta: Depdiknas.

Djaali dan Pudji Muljono (2007). Pengukuran dalam bidang pendidikan. Jakarta: Grasindo

Djamarah, Syaiful Bahri dan Aswan Zain. (2006). Strategi Belajar Mengajar. Jakarta: Rineka Cipta.

Fahmi (2013). Kemampuan Penguasaan Materi Pelajaran Guru SMA/MA Berdasarkan Hasil Ujian Nasional Rendah, Jurnal Pendidikan dan Kebudayaan, 19(2), 189-205

Gable, R. K. (1986). Instrumen development in affective domain. Boston:KluwerNijhoff Publishing.

Handoko, T. H. (1994). Manajemen personnalia dan sumber dayamanusia, Yogyakarta: BPFE

Idrus, A., \& Fachruddin, S. (2009). Pengembangan profesionalitas guru. Jakarta: Gaung Persada.

Kunandar (2007). Guru profesional. Jakarta : PT. Raja Grafindo Persada.

McBeath, R. J. (1992). Instructing and evaluating in higher education. New Jersey: Educational Tecchnology Publications Englewood Cliffs. 
Nitko, J. A., \& Brookhart, S. M. (2007). Educational assessment of students. New Jersey: Pearson Prentice Hall.

Permanasari, M. A. (2001), Analisis perbedaan prestasi kerja karyawan ditinjau dari segi usia, tingkat pendidikan dan masa kerja. Yogyakarta: Universitas Sanata Dharma.

Purwanto, N. (2013). Prinsip-prinsip dan teknik evaluasi pengajaran. Bandung: Remaja Rosdakarya.

Riyanto, A. (2003). Proses belajar mengajar efektif di perguruan tinggi. Bandung: Yapemdo.

Roestiyah, N. K. (1988). Strategi belajar mengajar: Salah satu unsur pelaksanaan strategi belajar mengajar (Teknik Penyajian). Jakarta: Bina Aksara

Rohani. A. (2004). Pengelolaan pengajaran. Jakarta: Rineka Cipta

Ruslan , Tati Fauziah , Tuti Alawiyah, (2016) Kendala Guru Dalam Menerapkan Penilaian Autentik di SD Kabupaten Pidie, Jurnal Ilmiah Pendidikan Guru Sekolah Dasar FKIP Unsyiah 1(1), 147-157

Sanjaya, W. (2005). Pembelajaran dalam implemntasi kurikulum berbasis kompetensi. Jakarta: Kencana Prenedia Media Group.

Sardiman, A. M. (2000). Interaksi dan motivasi belajar mengajar. Jakarta: Raja Grafindo Persada.

Saud, U. S. (2010). Pengembangan profesi guru. Bandung: Alfabeta.

Soekartawi (1995). Meningkatkan efektivitas mengajar. Jakarta: Pustaka Jaya .

Sumiyati (2005). Hubungan Antara Kreativitas, Kecerdasan Emosional, dan Penguasaan Materi dengan Kinerja Guru Kimia SMU di DKI, Disertasi, PPs Universitas Negeri Jakarta.

Suryabrata, S. (2005). Pengembangan alat ukur psikologis. Yogyakarta: Andi Ofset.

Suprihatiningrum, J. (2013). Guru profesional, pedoman kinerja kualifikasi dan kompetensi guru. Yogyakarta: Ar-Ruzz Media.

Supriyono, R. A. (2006). Pengaruh usia, keinginan sosial, kecukupan anggaran dan partisipasi penganggaran terhadap kinerja manajer di Indonesia. Jurnal Ekonomi dan Bisnis Indonesia, 21(1), 1-21.

Surbakti (2012). Pergumulan usia tengah baya. Jakarta: PT Elex Media Komputindo

Susanto, H. (2012). Faktor-faktor yang mempengaruhi kinerja guru sekolah menengah kejuruan. Jurnal Pendidikann Vokasi, 2(2), 197 -212.

Lumban tobing, S. (2006). Kecerdasan pada usia lanjut dan demensia. Jakarta: Balai Penerbit FKUI.

Uno, H. B. (2008). Model pembelajaran. Jakarta: Bumi Aksara. 
Widoyoko, S. Eko Putro (2013). Optimalisasi peran guru dalam evaluasi program pembelajaran, Jurnal Pendidikan, 22(2), 177-186.

Yusrizal, SoewarnoSdanZarlaidaFitri (2011). Evaluasi kinnerja guru fisika, biolog dan kimia SMA yang sudah lulus sertifikasi. Jurnal Penelitian dan EvaluasiPendidikan, 15(2), 72-89. 